\title{
Correspondence
}

\section{Accidental Epidural Narcotic Overdose}

To the Editor:

We wish to report the effects of a large dose of epidural morphine administered in error.

A healthy 24-year-old woman underwent gastric bypass surgery for obesity. She was $152 \mathrm{~cm}$ tali and weighed $98 \mathrm{~kg}$. Following an uneventful epidural and light general anaesthetic (using two per cent $\mathrm{CO}_{2}$ lidocaine, topped up twice during the operation) the patient was extubated awake in the $O R$, nursed sitting up, and taken to the surgical intensive care unit (SICU).

An analgesic order was written for epidural meperidine $50 \mathrm{mg}$ in $20 \mathrm{cc}$ normal saline to be given via the epidural catheter every three to four hours, as required. Forty-five minutes after the patient's arrival in SICU, she complained of pain and was mistakenly given $50 \mathrm{mg}$ morphine in $20 \mathrm{co}$ saline. The error was not immediately noted.

Ten hours later, the patient again complained of pain, and was given a second epidural dose of $50 \mathrm{mg}$ morphine. Five hours and 15 minutes after this second dose, when the $\mathrm{PCO}_{2}$ was 52, the error was noted. Naloxone $4 \mathrm{mg}$ was given intravenously; the patient woke up in pain. Innappropriately, 25 mg of epidural demerol was then given. One hour later the patient was again resting comfortably

Within the first eighteen hours following surgery the patient had received morphine $100 \mathrm{mg}$ as well as meperidine $25 \mathrm{mg}$ via her epidural catheter. The patient's level of consciousness, resting respiratory rate and $\mathrm{PaCO}_{2}$ at rest are recorded in the table.

Following the first $50 \mathrm{mg}$ epidural dose of morphine, only mild respiratory depression was noted, with a fall in resting respiratory rate to 18 . The patient was drowsy, but easily aroused. Analgesia lasted ten hours.

After the second epidural dose of $50 \mathrm{mg}$ morphine, respiratory depression was more marked, with a minimum resting respiratory rate of 12 , and a maximum rise in $\mathrm{PaCO}_{2}$ to 56, occurring 45 minutes after the epidural injection. The patient's nurse stated that at no time did she note the patient to be unrousable. Administration of IV naloxone five hours after the second dose of morphine resulted in only temporary, short-lived reversal of its opiate effects. Analgesia lasted for $22 \frac{3}{4}$ hours following the second $50 \mathrm{mg}$ dose of morphine.

TABLE

\begin{tabular}{|c|c|c|c|c|c|}
\hline Day & $\begin{array}{l}\text { Hours } \\
\text { post-op }\end{array}$ & Narcotic & $\mathrm{PaCO}_{2}$ & $\begin{array}{l}\text { Resring } \\
\text { resp rare }\end{array}$ & Level of consciousmess \\
\hline \multirow[t]{4}{*}{ Day 1} & 0 & & 34 & 20 & \\
\hline & 0.45 & Epidural morphine $50 \mathrm{mg}$ & & & Shivering, awake, and drowsy \\
\hline & 1.30 & & & 18 & \\
\hline & $2-10$ & & & $18-22$ & Drowsy, easily aroused and cooperative \\
\hline \multirow[t]{12}{*}{ Day 2} & $10.15 \mathrm{~h}$ & Epidural morphine $50 \mathrm{mg}$ & & & \\
\hline & 11 & & 52 & 12 & \\
\hline & 12 & & & 16 & \\
\hline & 13 & & 52 & 16 & \\
\hline & 15.30 & Naloxone IV $0.4 \mathrm{mg}$ & 20 & & Awake, wilh pain \\
\hline & 15.45 & Epidural meperidine $25 \mathrm{mg}$ & & & \\
\hline & 17 & & 53 & 16 & Up in chair for 40 min; drowsy \\
\hline & 18 & & & 16 & \\
\hline & 20 & & 51 & 16 & \\
\hline & 21 & & 54 & 20 & Up in chair, drowsy \\
\hline & $23-31$ & & $51-42$ & $18-20$ & Itch in upper chest when asked; awake \\
\hline & 33 & Meperidine IM $50 \mathrm{ngg}$ & 41 & 22 & First analgesic given for pain \\
\hline Day 3 & & & $37-41$ & $20-22$ & Meperidinc $100 \mathrm{mg} \times 3$ required for pain \\
\hline
\end{tabular}

CAN ANAESTH SOC J $1984 / 31: 5 /$ pp 594-6 
Usual doses of epicural morphine range from $2-10 \mathrm{mg}$; the duration of analgesia has been reported to be between two and 51.6 hours and is said to be dose-dependent.

It is interesting to note that in this patient, who inadvertently received $50 \mathrm{mg}$ plus $50 \mathrm{mig}$ of epidura] morphine and $25 \mathrm{mg}$ of epidural meperidine within a 16 hour-period that:

1 Respiratory depression was not as severe as one would expect.

2 At no time was the patient unrousable.

3 Analgesia lasted only ten hours and 23 hours after doses of $50 \mathrm{mg}$ of epidural morphine - much shorter than would have been expected if duration was dose-dependent.

4 The second equipotent dose of morphine lasted 2.5 times as long as the initial dose (both given in 20 ce of saline).

There is current debate as to the dose of morphine, and volume of solution required to provide analgesia. This patient twice received five times the recommended dose used, within a ten-hour period. The lack of severe side effects (respiratory arrest or loss of consciousness) perhaps lends support to those who feel that higher doses of epidural morphine can be used in the closely monitored patient with relative safety.

\section{REFERENCES}

1 Magora F. Olshwang D, Amert D et al. Observalions on extradural morphine analgesia in various pain conditions. Br J Anaesth 1980; 52: 247-52.

2 Chayen MS, Rudick $V$, Borvine A, Pain control with epidural injection of morphine. Anesthesiology 1980: 53: 338-9.

3 Rawal N, Sjustrand U, Dahlstrom B. Postoperative pain relief by epidural morphine. Anesth Analg $1981 ; 60: 726-31$.

4 Bramage $P R$, Camporesi E, Chestnut D. Epidural narcolics for postoperative analgesia. Ancsth Analg $1980 ; 59: 473-80$.

5 Nordberg $G$, Hedner $T$, Mellstrand $T$, Dahlstrom $B$. Pharmacokinetic aspects of epidural morphine analgesia. Anesthesiology 1983; 58: 545-51.

Richard J.S Robinson MD

Serge Lenis MD

Marlene Elliot RN

Department of Anaesthesia

Montreal General Hospital

Montreal, Quebec

\section{A Simple Wheel Guard for Anaesthetic Gas Machines}

\section{To the Editor:}

The increasing numbers of mechanical and electrical equipment in use in the operating room have further complicated the manoeuvreability of anaesthetic equipment. The number of wires and gas hoses on the operating room floor makes it difficult to move this equipment when they are located in its vicinity. By adding a wheel guard (Figures 1 and 2) it becomes very easy to move the anaesthetic gas machine and it provides also an excellent protection against damage to the wires or gas hoses. This whecl guard is $14 \mathrm{~cm}$ long, $9 \mathrm{~cm}$ high and $4 \mathrm{~cm}$ width to cover a $12 \mathrm{~cm}$ diameter wheel, It is made of a 16 gauge stell, painted black. There is a slot on

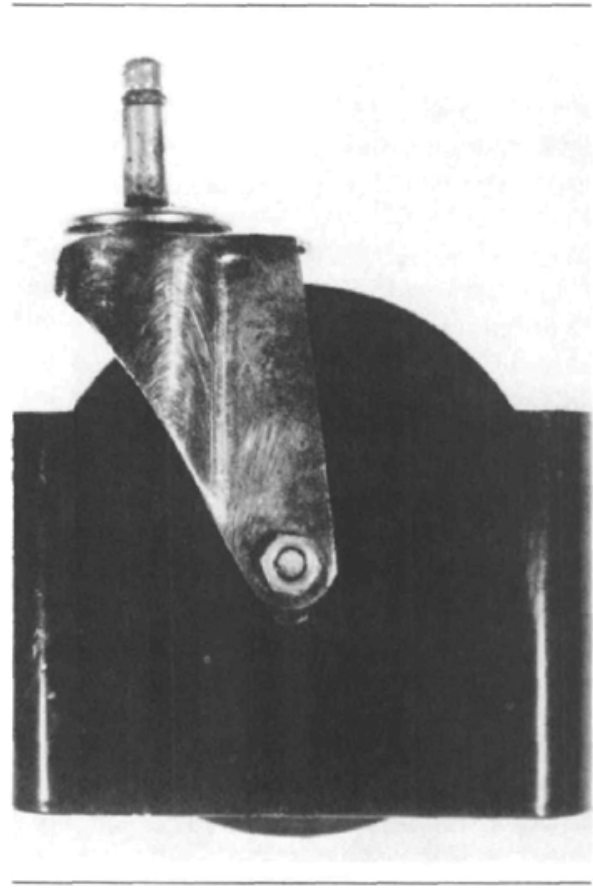

FIGURE I Wheel guard. 